\title{
MOLECULAR DETECTION OF ENTEROTOXIGENIC GENES FOR STAPHYLOCOCCUS AUREUS ORGANISM ISOLATED FROM RAW MILK AND SOME MILK PRODUCTS
}

\author{
SADEK, O.A. ${ }^{1}$ AND KORIEM, A.M. ${ }^{2}$ \\ ${ }^{1}$ Food Hygiene Department, Assiut Lab., Animal Health Research Institute, ARC, Egypt. \\ ${ }^{2}$ Bacteriology Department, Assiut Lab., Animal Health Research Institute, ARC, Egypt.
}

Received: 14 September 2020; Accepted: 5 October 2020

This study aimed to determine Staph. aureus in raw milk and some milk products and study the correlation between Staph. aureus enterotoxin genes and its ability to resist different types of antibiotics. A total of 120 raw milk, kareish cheese and baladi yoghurt (40 samples, each) were collected from different dairy shops and street peddlers in Assiut city, Egypt and were bacteriologically examined for presence and count of Staph. aureus. The incidences of counted Staph. aureus in raw milk, kareish cheese and baladi yoghurt were 62.5, 27.5 and $0.0 \%$, respectively, with average counts of $3.25 \mathrm{log}, 4.13 \mathrm{log}$ and $<1 \mathrm{log}$ cfu/ml, respectively. All the isolated Staph. aureus strains were tested by Multiplex PCR assay for the presence of enterotoxigenic sea, seb, sec and sed genes and $94.44 \%$ of the tested strains harbored sea gene and $2.77 \%$ were positive for sed gene, while none of the tested strains was positive for seb and sec gene. The recovered organisms exhibited 52.78, 11.11, 77.78, 61.11, 11.11, 36.11, 63.89 and $16.67 \%$ resistance towards Oxacillin (Methicillin), Vancomycin, Amoxicillin, Ceftriaxone, Gentamicin, Tetracycline, Erythromycin, and Trimethoprim-Sulfamethoxazole, while, they exhibited $100 \%$ sensitivity towards Ciprofloxacin. The tested organisms showed multi-antibiotics resistance percentage of $55.56 \%$ and with average resistance index of 0.37 . The correlation between Staph. aureus enterotoxin genes and its ability to resist different types of antibiotics revealed that, most of the enterotoxigenic strains were multi-antibiotics resistance and resist simultaneously to Amoxicillin, Ceftriaxone and Erythromycin. All the methicillin resistant Staph. aureus (MRSA) isolates harbored sea gene. The public health hazards of Staph. aureus in milk and its products as well as the suggestive control measures were discussed.

Keywords : Staphylococcus aureus, enterotoxigenic genes, raw milk, kareish cheese, yoghurt, PCR

\section{INTRODUCTION}

In humans, Staph. aureus is considered a well-documented opportunistic pathogen. It may cause food poisoning, pneumonia, skin infections,

Corresponding author: SADEK, O.A.

E-mail address: onsi_2000@yahoo.com

Present address: Food Hygiene Department, Assiut Lab., Animal Health Research Institute, ARC, Egypt enterotoxemia, and septicemic infections; furthermore, it is important as the cause of toxic shock syndrome (TSS) (Sidhu et al., 2007). With the emergence of methicillinresistant Staph. aureus (MRSA) and its increasing resistance towards antibiotics of various groups such as penicillins, cephalosporins, fluoroquinolones, aminoglycosides and macrolides. Vancomycin has been the antibiotic of the last resort to treat the hospitalized patients 
critically infected with MRSA or other Gram-positive organisms like Clostridium difficile. While, widespread use of Vancomycin to treat infections caused by methicillin resistant Staph. aureus (MRSA) and other Gram-positive cocci has led to the emergence of Vancomycin resistance (VRSA). The large scale of spread of resistance to Vancomycin has been perceived as a fearsome threat to the already challenging therapy of MRSA (Moellering, 2008 and Abdel-Baky et al., 2014). Antibiotic-resistant strains of bacteria cause humans to become more virulently ill for longer periods of time than their antibiotic susceptible counterparts. Treatment failure occurs as a consequence and there is the need for expensive and/or toxic alternative drugs which in most cases are more expensive (WHO, 2007).

Enterotoxigenic Staph. aureus is one of the major pathogens causing food poisoning cases worldwide. Staphylococcal enterotoxins (SE) are emetic toxins and are classified as members of the pyrogenic toxin superantigen family because of their biological activities and structural relatedness (Dinges et al., 2000). Staphylococcal food poisoning is associated with contaminated foods of animal origin, such as milk and dairy products and other protein rich animal origin foods such as ice cream, meat, poultry and fish (Janštová et al., 2012).

The staphylococcal food poisoning (SFP) is a mild intoxication occurring after the ingestion of food containing from $20 \mathrm{ng}$ up to1 $\mu \mathrm{g}$ of Staphylococal enterotoxins (SEs) which is enough to induce symptoms in human beings (Normanno et al., 2007). The SFP symptoms appear 1-6 h after ingestion of contaminated food, depending on individual and toxic dose ingested. They include nauseas, abdominal cramps, diarrhea, general malaise, weakness and characteristic projectile vomiting. Clinical signs of SFP generally disappear within 24$48 \mathrm{~h}$. Deaths occur rarely and specifically in the very young or elderly (Jay et al., 2005). The five classical enterotoxins (SEs type A, $\mathrm{B}, \mathrm{C}, \mathrm{D}$ and $\mathrm{E})$ were known to be responsible for $95 \%$ of SFP cases, the rest of cases were due to the new types of SEs (SE G - SE O) (Wang et al., 2012).

Milk; kareish cheese (traditional Egyptian cheese made from raw skimmed milk) and baladi yoghurt (small scale yoghurt) act as a good vehicle for Staph. aureus organisms and sometimes this organisms may be antibiotic resistant and enterotoxins producers. Therefore, the aim of this study was to determine the prevalence of Staph. aureus in raw milk, kareish cheese and baladi yoghurt sold in Assiut City, Egypt and testing them for antimicrobial sensitivity test for detection of MRSA and VRSA strains and application of multiplex PCR to detect some classical enterotoxins genes (sea, seb, sec and sed) in the isolated strains.

\section{MATERIALS AND METHODS}

A total of 120 raw milk, kareish cheese and baladi yoghurt samples (40 samples, each) were collected from dairies and street peddlers in Assiut city, Egypt during the period from December 2018 to April 2019. The samples were collected in clean and sterile plastic bags in an ice-box and transferred rapidly as soon as possible to the laboratory for bacteriological examination.

\section{A) Preparation of samples:}

The apparently normal raw milk samples were mixed thoroughly and tested for heat treatment by Storch test according to Lampert (1975) before being subjected to examination. Ten $\mathrm{ml}$ from liquid samples or $10 \mathrm{~g}$ from the prepared solid samples were added individually to $90 \mathrm{ml}$ of $0.1 \%$ sterile peptone water. Ten-fold serial dilutions from each sample were done up to $10^{6}$ (A.P.H.A., 2001). 
B) Isolation and enumeration of Staph. aureus from the prepared samples:

1) Enrichment procedure according to Lee (2003): $10 \mathrm{ml}$ milk or $10 \mathrm{gm}$ of each prepared cheese and yoghurt samples were inoculated into $10 \% \mathrm{NaCl}$ nutrient broth and incubated at $35^{\circ} \mathrm{C}$ for $20 \mathrm{~h}$.

2) Isolation of Staph. aureus by selective plating on mannitol salt agar according to Finegold and Martin (1982): Loopfulls from the incubated $10 \% \mathrm{NaCl}$ nutrient broth tubes were streaked on mannitol salt agar plates then incubated at $37^{\circ} \mathrm{C}$ for $48 \mathrm{~h}$. Suspected golden yellow colonies with yellow halo were picked up onto nutrient agar slant and incubated at $37^{\circ} \mathrm{C}$ for 24 hour before being subjected to identification.

3) Enumeration of Staph. aureus, using Baird-Parker agar, according to FDA (2001): From each dilutions, $1.0 \mathrm{ml}$ was spread onto large plate Baird-Parker agar with sterile bent glass rod and incubated at $37^{\circ} \mathrm{C}$ for 24 hours. Then the numbers of small black, shiny with narrow white margins and surrounded by clear zones extended into the opaque medium were calculated and typical colonies were picked into nutrient agar slants for biochemical identification.

\section{C) Identification of Staph. aureus organism.}

1) Gram's stain showed Gram positive cocci forming an irregular grape like clusters.

2) Catalase activity test according to FDA (2001) where the organism was catalase positive.

3) Tube coagulase test according to FDA (2001): Sterile rabbit plasma was diluted 10 folds with sterile normal saline. 0.5 $\mathrm{ml}$ of the diluted plasma was put in each 2 Wassermann tubes. Five drops of overnight incubated broth culture at $37^{\circ} \mathrm{C}$ were added to first tube, while the other was left to serve as a control. The tubes were incubated at $37^{\circ} \mathrm{C}$ and then examined after one and $24 \mathrm{~h}$ incubation for coagulation.

4) Anaerobic utilization of mannitol according to FDA (2001): Pure culture of the isolated organisms were inoculated into peptone water containing mannitol $(0.5 \%)$ and bromocresol purple as indicator and the surface of the medium were covered by sterile paraffin oil at least $25 \mathrm{~mm}$ thick. The tubes were incubated for 5 days at $37^{\circ} \mathrm{C}$. Acid was produced anaerobically; if the indicator is changed to yellow color throughout the tubes indicates the presence of Staph. aureus.

5) Detection of haemolysis according to Bailey and Scott (1994): Isolated strains were cultured on blood agar plates contained $10 \%$ sheep blood and incubated at $37^{\circ} \mathrm{C}$ for $24 \mathrm{~h}$ for detection the type of haemolysis.

D) Antibiogram of Staph. aureus species according to CLSI (2011): Each Staph. aureus was standardized using colony suspension methods and strain's suspension diluted with sterile saline and adjusted to 0.5 McFarland standards. The antibiotic susceptibility testing was determined using the modified KirbyBauer disc diffusion technique (CLSI (2011) by swabbing onto MuellerHinton agar plates with the resultant saline suspension of each strain and the following (9) antibiotic discs were placed on the plate: Oxacillin (Methicillin) $1 \mu \mathrm{g}$, Vancomycin $30 \mu \mathrm{g}$,

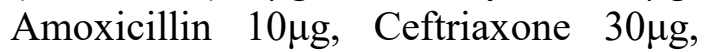
Gentamicin 10 $10 \mathrm{~g}$, Tetracycline $30 \mu \mathrm{g}$, Erythromycin $15 \mu \mathrm{g}$, TrimethoprimSulfamethoxazole $25 \mu \mathrm{g}$ and Ciprofloxacin $5 \mu \mathrm{g}$. The plates containing the discs were allowed to stand for at least $30 \mathrm{~min}$ before incubated at $30^{\circ} \mathrm{C}$ for $24 \mathrm{~h}$ so as to favor the growth of methicillin resistant strains (BSAC, 2002). The diameter of the zone of inhibition produced by each antibiotic 
disc was measured and interpreted using the CLSI zone diameter interpretative standards.

Antibiotic resistance (ARI) index was calculated as $\mathrm{a} / \mathrm{b}$, where "a" represents the number of antibiotics to which the isolates were resistant and "b" represents the total number of antibiotics to which the isolate was exposed (Krumperman, 1983).

E) Multiplex Polymerase Chain Reaction (m PCR): for detection of sea, seb, sec, and sed genes in the isolated Staph. aureus strains which was done in Animal Reproduction Research Institute, El Haram, Giza, Egypt.

\section{1- DNA extraction:}

A crude extraction method based on boiling procedure was used to prepare template
DNA from bacterial strains according to Reischl et al. (1994). Two to 5 loops of bacteria taken from the brain heart infusion agar plate were collected and suspended in $200 \mu \mathrm{l}$ of lysis buffer comprised of $1 \%$ Triton X-100, 0.5\% Tween 20, $10 \mathrm{mM}$ Tris- $\mathrm{HCl}$ (pH 8.0), and $1 \mathrm{mM}$ EDTA. After boiling for $10 \mathrm{~min}$, the suspension was centrifuged for 2 min to sediment bacterial debris. The supernatant was aspirated and kept at $-20^{\circ} \mathrm{c}$ as source for DNA to be used directly for PCR amplification.

\section{2- Primers:}

Primers used for PCR amplification were synthesized in Bio Basic Inc. (Canada). Details of primer sequences, their specific target genes, references, annealing temperature and amplicon sizes are summarized in the following table:

\begin{tabular}{|c|c|c|c|c|c|c|c|c|}
\hline \multirow{2}{*}{$\begin{array}{l}\text { Gene } \\
\text { targeted }\end{array}$} & \multirow{2}{*}{$\begin{array}{l}\text { Primer sequence } \\
5 "-3 "\end{array}$} & \multirow{2}{*}{ references } & \multirow{2}{*}{$\begin{array}{l}\text { Amplified } \\
\text { segment } \\
\text { (bp) }\end{array}$} & \multirow{2}{*}{$\begin{array}{c}\text { Primary } \\
\text { denaturation }\end{array}$} & \multicolumn{3}{|c|}{ Amplified cycles } & \multirow{2}{*}{$\begin{array}{c}\text { Final } \\
\text { extension }\end{array}$} \\
\hline & & & & & $\begin{array}{c}\text { Secondary } \\
\text { denaturation }\end{array}$ & annealing & Extension & \\
\hline sea & $\begin{array}{l}\text { TAAGGAGGTGGTGCCTATGG } \\
\text { CATCGAAACCAGCCAAAGTT }\end{array}$ & $\begin{array}{c}\text { Cremonesi } \\
\text { et al., } \\
2005\end{array}$ & 180 & \multirow{4}{*}{$\begin{array}{c}94^{\circ} \mathrm{C} \text { for } 5 \\
\min \end{array}$} & \multirow{4}{*}{$\begin{array}{l}30 \text { cycle at } \\
94^{\circ} \mathrm{C} \text { for } 1 \\
\min \end{array}$} & \multirow{4}{*}{$\begin{array}{c}56^{\circ} \mathrm{C} \text { for } \\
1 \mathrm{~min}\end{array}$} & \multirow{4}{*}{$\begin{array}{l}68^{\circ} \mathrm{C} \text { for } \\
1 \mathrm{~min}\end{array}$} & \multirow{4}{*}{$\begin{array}{c}72^{\circ} \mathrm{C} \text { for } \\
7 \mathrm{~min}\end{array}$} \\
\hline seb & $\begin{array}{l}\text { TCGCATCAAACTGACAAACG } \\
\text { GCAGGTACTCTATAAGTGCC }\end{array}$ & $\begin{array}{c}\text { Johnson et } \\
\text { al., } 1991\end{array}$ & 478 & & & & & \\
\hline $\mathrm{sec}$ & $\begin{array}{l}\text { GACATAAAAGCTAGGAATTT } \\
\text { AAATCGGATTAACATTATCC }\end{array}$ & $\begin{array}{c}\text { Johnson et } \\
\text { al., } 1991\end{array}$ & 257 & & & & & \\
\hline sed & $\begin{array}{l}\text { CTAGTTTGGTAATATCTCCT } \\
\text { TAATGCTATATCTTATAGGG }\end{array}$ & $\begin{array}{c}\text { Johnson et } \\
\text { al., } 1991\end{array}$ & 317 & & & & & \\
\hline
\end{tabular}

\section{3- DNA amplification reaction:}

Multiplex PCR assay was used that detect staphylococcal enterotoxines A, B, C and D genes. The amplification cycles were carried out in Nexus gradient Master cycler (Eppendorf, Germany). The reaction condition was optimized to be $94^{\circ} \mathrm{C}$ for $5 \mathrm{~min}$. as initial denaturation, followed by 30 cycles of $94^{\circ} \mathrm{C}$ for 60 seconds as secondary denaturation, annealing for 60 seconds at $56^{\circ} \mathrm{C}$ and extension at $68^{\circ} \mathrm{C}$ for
60 seconds. A final extension step at $72^{\circ} \mathrm{C}$ for $7 \mathrm{~min}$. was followed. PCR reaction was optimized using a total volume of $20 \mu \mathrm{L}$ reaction mixtures which contained $3 \mu \mathrm{L}$ of DNA as template, 20pmol of each primer, 1X of PCR master mix (Dream Taq Green PCR Master Mix, Fermentas Life Science). PCR products were analyzed by electrophoresis in $1.5 \%$ agarose gel in $0.5 \mathrm{X}$ TBE buffer containing ethidium bromide and visualized under a UV transilluminator. 


\section{RESULTS}

Table 1: Statistical analytical results of Staph. aureus counts in raw milk, kareish cheese and yoghurt samples ( $\mathrm{n}=40$ of each).

\begin{tabular}{cccccccccc}
\hline & \multicolumn{7}{c}{ S. aureus count (cfu/g) } \\
\cline { 2 - 8 } Sample type & Positive samples & \multicolumn{1}{c}{ Negative samples } & Min. & Max. & Average & \pm SE \\
\cline { 2 - 8 } & No. & $\%$ & No. & $\%$ & & & & \\
\hline Milk & 25 & 62.50 & 15 & 37.50 & $<1 \log$ & $4.53 \log$ & $3.25 \log$ & $2.93 \log$ \\
\hline $\begin{array}{c}\text { Kareish } \\
\text { cheese }\end{array}$ & 11 & 27.50 & 29 & 72.50 & $<1 \log$ & $5.51 \log$ & $4.13 \log$ & $3.93 \log$ \\
\hline yoghurt & 0 & 0.0 & 40 & 100 & $<1 \log$ & - & - & - \\
\hline
\end{tabular}

Table 2: Frequency distribution of Staph. aureus counts in the examined raw milk and kareish cheese samples $(n=40$ of each).

\begin{tabular}{ccccc}
\hline \multirow{2}{*}{ Intervals } & \multicolumn{2}{c}{ Raw milk } & \multicolumn{2}{c}{ Kareish cheese } \\
\cline { 2 - 5 } & No. & $\%$ & No. & $\%$ \\
\hline$<10^{2}$ & 15 & 37.5 & 29 & 72.5 \\
\hline $\log 2-<\log 3$ & 8 & 20 & 1 & 2.5 \\
\hline $\log 3-<\log 4$ & 16 & 40 & 3 & 7.5 \\
\hline $\log 4-<\log 5$ & 1 & 2.5 & 5 & 12.5 \\
\hline $\log 5-<\log 6$ & 0 & 0.0 & 2 & 100 \\
\hline Total & 40 & 100 & 40 & 5
\end{tabular}


Table 3: Antibiogram of Staph. aureus organisms isolated from raw milk and kareish cheese $(n=36)$

\begin{tabular}{ccccc}
\hline \multirow{2}{*}{ Antibiotics } & \multicolumn{2}{c}{ Resist } & \multicolumn{2}{c}{ Sensitive } \\
\cline { 2 - 5 } & No./36 & $\%$ & No./36 & $\%$ \\
\hline Oxacillin (Methicillin) & 19 & 52.78 & 17 & 47.22 \\
\hline Vancomycin & 4 & 11.11 & 32 & 88.89 \\
\hline Amoxicillin & 28 & 77.78 & 8 & 22.22 \\
\hline Ceftriaxone & 22 & 61.11 & 14 & 38.89 \\
\hline Gentamicin & 4 & 11.11 & 32 & 88.89 \\
\hline Tetracycline & 13 & 36.11 & 23 & 63.89 \\
\hline Erythromycin & 23 & 63.89 & 13 & 36.11 \\
\hline Trimethoprim-Sulfamethoxazole & 6 & 16.67 & 30 & 83.33 \\
\hline Ciprofloxacin & 0 & 0.0 & 36 & 100 \\
\hline
\end{tabular}

Table 4: Percentage of multi-antimicrobial resistant (MAR) of Staph. aureus organisms isolated from raw milk and kareish cheese $(\mathrm{n}=36)$.

\begin{tabular}{ccc}
\hline \multicolumn{2}{c}{ Multi-antimicrobial resistant Staph. aureus organisms } & \multirow{2}{*}{ Average of RI } \\
\cline { 1 - 2 } No./36 & $\%$ & 0.37 \\
\hline 20 & 55.56 & \\
\hline
\end{tabular}

Table 5: Frequency of antimicrobial resistant index (ARI) of Staph. aureus organisms isolated from raw milk and kareish cheese $(n=36)$.

\begin{tabular}{ccc}
\hline ARI & Frequency & $\%$ \\
\hline 0.1 & 4 & 11.11 \\
\hline 0.2 & 3 & 8.33 \\
\hline 0.3 & 4 & 11.11 \\
\hline 0.4 & 8 & 22.22 \\
\hline 0.5 & 8 & 22.22 \\
\hline 0.6 & 3 & 8.33 \\
\hline 0.7 & 1 & 2.78 \\
\hline 0.8 & 0 & 0 \\
\hline 0.9 & 0 & 0 \\
\hline 1 & 0 & 0 \\
\hline
\end{tabular}

Table 6: Percentage of Staph. aureus strains positive for enterotoxigenic genes by using Multiplex PCR assay.

\begin{tabular}{cccc}
\hline \multirow{2}{*}{ Gene targeted } & \multirow{2}{*}{ No. of tested strains } & \multicolumn{2}{c}{ Positive strains } \\
\cline { 3 - 4 } & 36 & No. & $\%$ \\
\hline sea & 36 & 0 & 94.44 \\
\hline seb & 36 & 0 & 0.0 \\
\hline sed & 36 & 1 & 0.0 \\
\hline
\end{tabular}




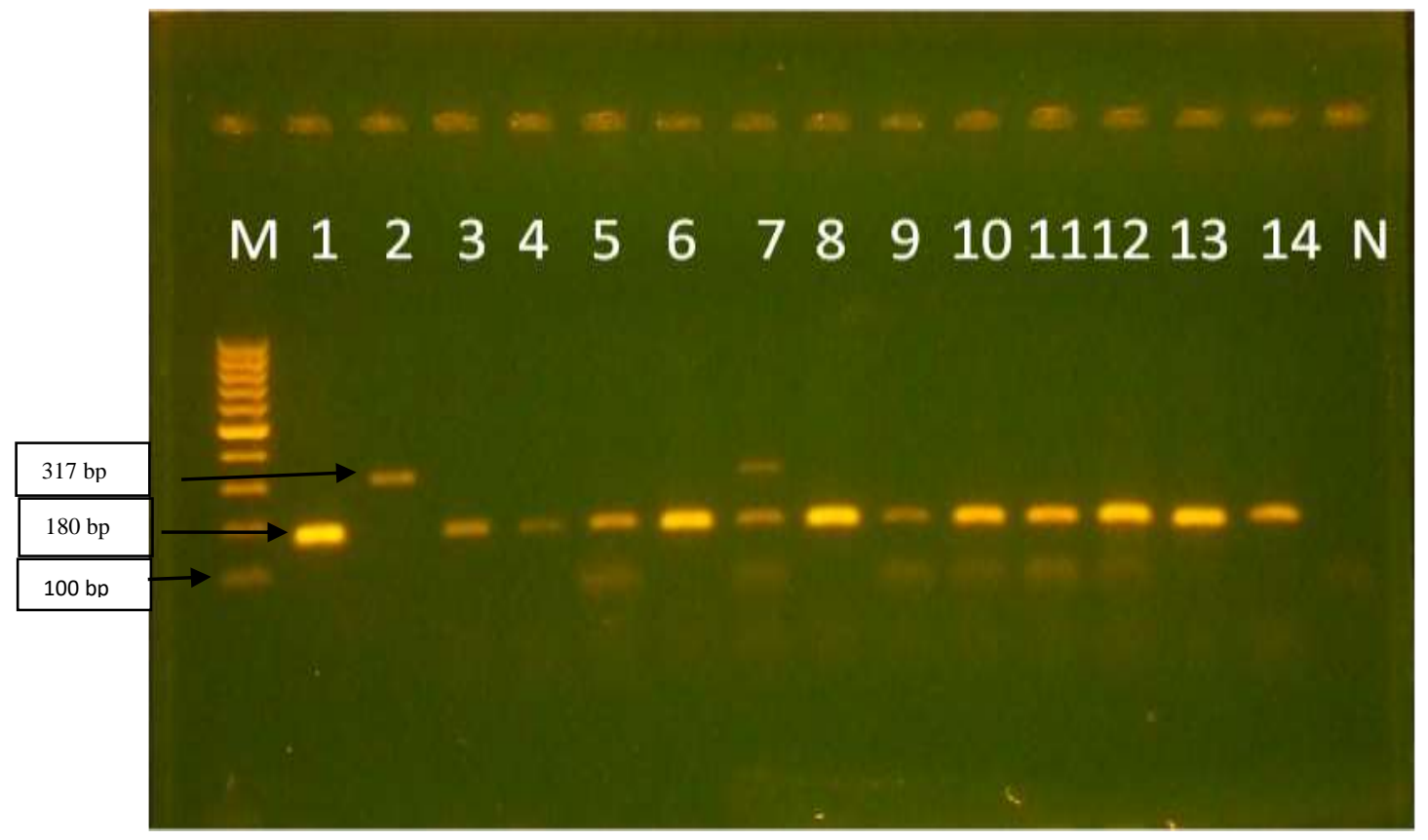

Figure 1: The electrophoresis pattern of Multiplex PCR amplicon on Staph. aureus strains for detection enterotoxigenic sea, seb, sec and sed genes.

M: 100 bp ladder DNA marker

Lane 1: sea control positive Staph. aureus (180 bp)

Lane 2: sed control positive Staph. aureus (317 bp)

Lane 3-6 and 8-14: sea positive isolates

Lane 7: sea and sed positive isolate

$\mathrm{N}$ : Negative control.

N.B.: control positive for seb and sec Staph. aureus strains were not available during performance of this study.

\section{DISCUSSION}

Results illustrated in Table 1 revealed that, the prevalence of Staph. aureus in the examined raw milk samples was $62.50 \%$, with counts ranging from $<1 \log$ to 4.53 $\log$ and with an average count of $3.25 \log$ cfu/ml. Nearly similar result $(64 \%)$ was revealed by Yildirim et al. (2019). Lower incidence of $16.3 \%$ was found by Mansour et al. (2017), whereas higher incidence (94\%) was recorded by Kamal et al. (2013).

Table 2 revealed that, the highest frequency distribution of positive Staph. aureus count in raw milk samples was $40 \%$ and in the range of $\log 3-<\log 4 \mathrm{cfu} / \mathrm{ml}$. Presence of Staph. aureus in raw milk in this study could be attributed to either indigenous source due to Staph. aureus subclinical mastitis or exogenous source from infected handler's hands or from sneezing and cough. Also, contaminated utensils and infected flies and insects could be a source of contamination.

The prevalence of Staph. aureus in kareish cheese samples was $27.50 \%$, with counts ranging from $<1 \mathrm{log}$ to $5.51 \mathrm{log}$ and with an average count of $4.13 \mathrm{log} \mathrm{cfu} / \mathrm{g}$ (Table $1)$. Relatively similar result of $24 \%$ was estimated by Elmaghraby et al. (2018). On the contrary, higher incidence (93\%) was found by Kamal et al. (2013).

The highest frequencies distribution of positive Staph. aureus in kareish cheese samples was $12.5 \%$ and in the range $\log 4$ - 
$<\log 5 \mathrm{cfu} / \mathrm{g}$ (Table 2). The presence of Staph. aureus in kareish cheese is attributed to; this type of cheese is made from raw skimmed milk without any heat treatment and also, contaminated utensils and improper storage could be a sources of contamination such type of cheese with Staph. aureus and other public health important pathogens.

From the public health point of view, most of the isolated Staph. aureus strains from raw milk and kareish cheese in this study had count equal to or more than $10^{3} \mathrm{cfu} / \mathrm{ml}$ (Table 2) and this count is sufficient for the organism to produce enterotoxins responsible for occurrence of food poisoning to consumers as Jablonski and Bohach (2001) have found Staph. aureus counts in the range from $10^{3}-10^{5} \mathrm{CFU} / \mathrm{g}$ to be able to produce enterotoxin in such high quantities that may pose a health risk to the consumers.

The results listed in Table 1 revealed that, the prevalence of Staph. aureus in baladi yoghurt samples was $0.0 \%$, with a count of $<1 \log \mathrm{cfu} / \mathrm{g}$. This result coincided with Sadek et al. (2014a). Incidence of $14 \%$ was recorded by Zakary et al. (2011), while extremely higher incidence (88\%) was revealed by Meshref et al. (2019). The absence of Staph. aureus in baladi yoghurt in this study could be attributed to either heat treatment of milk during yoghurt production or due to acidity of baladi yoghurt which might play a role in Staph. aureus inhibition and hampering its growth.

The tabulated results in Table 3 showed that, Staph. aureus exhibited 52.78\% resistance towards Oxacillin (Methicillin). Relatively similar result of $55.9 \%$ was found by Hoque et al. (2018). On the other hand, lower result (9\%) was detected by Wang et al. (2017), while Omoshaba et al. (2018) revealed higher result of $88.2 \%$.
It is worth mentioning that; Methicillin resistant Staph. aureus (MRSA) is a potential health hazard especially in immune-compromised individuals, the treatment of MRSA infections is difficult and costly. The ability of these bacteria to spread multiple antimicrobial resistance genes, turning it into a major public health problem. Therefore, monitoring MRSA from food is important and improving hygiene standards in food practices in order to reduce the microbiological risk to minimum (Kluytmans et al., 1995; Pinchuk et al., 2010 and Basanisi et al., 2017).

Out of 36 Staph. aureus isolates, 4 isolates (11.11\%) were resist to Vancomycin (Table $3)$. Lower result of $2.8 \%$ was revealed by Breves et al. (2015); while, higher result (20.13\%) was reported by El-Banna et al. (2015).

All of the four Vancomycin resistant isolates obtained in this study were from raw milk samples and all of them were resisting simultaneously to Oxacillin (Methicillin), Amoxicillin and Erythromycin. While, 3 strains were resisting to Ceftriaxone and 2 strains were resist to Tetracycline.

From the public health point of view, Vancomycin has been the antibiotic of the last resort to treat the hospitalized patients critically infected with Methicillin resistant Staph. aureus MRSA (Moellering, 2008). Therefore, the presence of Vancomycin resistant Staph. aureus in raw milk at this study is of special public health concern and good hygienic measures must be applied during production of milk and milk products to safeguard consumers from being infected with such organism.

Concerning Amoxicillin, $77.78 \%$ of Staph. aureus isolates were resistant (Table 3). Lower result (42\%) was revealed by Hoque et al. (2018). On the other hand $81.8 \%$ 
resistant was revealed by Papadopoulos et al. (2018). For Ceftriaxone, $61.11 \%$ of the isolates were resistant (Table 3). Lower result of $34.8 \%$ was recorded by Sadek et al. (2014b). In regard to Gentamicin, $11.11 \%$ of the tested isolates were resistant. Relatively, similar result $(13.2 \%)$ was found by Wang et al. (2017).

The tested isolates exhibited resistance to Tetracycline, Erythromycin and Trimethoprim-Sulfamethoxazole in percentages of $36.11,63.89$ and $16.67 \%$, respectively (Table 3). Resistance of 38.2, 52.1 and $6.1 \%$ were reported respectively for the previous antibiotics by Wang et al. (2017). None of tested isolates was resistant to Ciprofloxacin in this study and this result coincided with Jung et al. (2005).

The illustrated results in Tables 4 and 5 revealed that, $55.56 \%$ of the tested isolates were Multi-antimicrobial resistant and with average resistance index (RI) of 0.37 and only $11.11 \%$ of the isolates showed resistance index of 0.1 . This result indicated that, the isolates recovered from samples originated from high-risk sources and milk is a possible transmitter of these microorganisms to humans with difficulty to eradicate the infection (Krumperman, 1983; Pinchuk et al., 2010 and Hammad et al., 2012).

Concerning enterotoxins, out of the 36 Staph. aureus isolates 34 isolates (23 isolates from raw milk and 11 isolates from kareish cheese) (94.44\%) were positive for sea gene (Table 6). Nearly similar result found by Wang et al. (2018) as the authors reported that, $94.8 \%$ Staph. aureus harbored at least one virulence gene from which sea $(60.4 \%)$ genes was detected. Also, from Table (6 and Fig. 1) only one isolate $(2.77 \%)$ was positive for sed gene which is co-positive with sea gene and this result simulated what obtained by Jung et al. (2005). Furthermore, no seb and sec genes were detected from the isolated
Staph. aureus in the present study and this result coincided with Jung et al. (2005).

From the obtained results in this study it is observed that, sea gene was the most prominent gene detected in Staph. aureus isolated from the examined samples and this observation go parallel with Argudin et al. (2010) as they concluded that, sea gene is the most common enterotoxin found in food and is frequently associated with staphylococcal food-poisoning outbreaks worldwide. Moreover, Enterotoxin does not affect foods' taste, odor, and appearance; they are heat resist and retain their biological activity even after pasteurization. Also, they resist the majority of proteolytic enzymes and thus remain their action in the gastrointestinal tract (Le Loir et al., 2003; Orwin et al., 2003 and Rall et al., 2008).

It is worth mentioning that; all the methicillin resistant Staph. aureus (MRSA) detected in this study, harbored sea gene from which one isolate of them harbored both sea and sed genes simultaneously and this observation indicated that, the isolated Staph. aureus strains from this study were of potential public health hazards as they are Methicillin resistant and enterotoxins producers.

The correlation between Staph. aureus enterotoxin genes and its ability to resist different types of antibiotics revealed that, most of the enterotoxigenic strains were multi-antibiotics resistance and resist simultaneously to Amoxicillin, Ceftriaxone and Erythromycin. All the methicillin resistant Staph. aureus (MRSA) isolates harbored sea gene. Moreover, the enterotoxigenic sea and sed positive strain was Oxicillin (Methicillin) resistance. Furthermore, the 2 negative enterotoxigenic Staph. aureus strains were multi-antibiotic resistance; one of them was sensitive to Methicillin and Vancomycin while the other was resist to them, in addition all of the 2 strains were sensitive to gentamycin. 


\section{CONCLUSION}

The present study revealed that, Staph. aureus organisms isolated from raw milk and kareish cheese samples were resist to different varieties of antibiotics and with high multi-drug resistant (MDR) percent and with high resistance index (RI). Methicillin resistant Staph. aureus (MRSA) and Vancomycin resistant Staph. aureus (VRSA) were detected in the isolated strains which represent a potential hazard to consumers. Counts of the most isolated Staph. aureus were sufficient to produce enterotoxins responsible for occurrence of food poising to consumers. Staph. aureus enterotoxin A gene was the most prominent gene in the isolated strains. All the methicillin resistant Staph. aureus (MRSA) strains harbored sea gene representing potential risks of infection and intoxication by consumption of such food. Thorough food inspection and frequent bacteriological surveillance by food control agencies is highly recommended to control the incidence of Staph. aureus in raw milk and dairy products to safeguard the consumers from risks of food poisoning.

\section{REFERENCES}

\section{A.P.H.A. (2001): Compendium of Methods} for the Microbiological Examination of Foods. $4^{\text {th }}$ Ed. American Public Heath Association, Washington, DC, USA.

Abdel-Baky, R.M.; Ahmed, H.R. and Gad, G.F.M. (2014): Prevalence and conjugal transfer of vancomycin resistance among clinical isolates of Staphylococcus aureus. AIR., 2(1): 12-23.

Argudin, M.A.; Mendoza, M.C. and Rodicio, M.R. (2010): Food poisoning and Staphylococcus aureus enterotoxins. Toxins, 2: 1751-1773.

Bailey, W.R. and Scott, E.G. (1994): Diagnostic Microbiology. A text book for the isolation and identification of pathogenic microorganisms. $9^{\text {th }}$ Ed., C.V. Mosby Co., St. Louis, Toronto, London.

Basanisi, M.; La Bella, G.; Nobili, G.; Franconieri, I. and La Salandra, G. (2017): Genotyping of methicillinresistant Staphylococcus aureus (MRSA) isolated from milk and dairy products in South Italy. Food Microbiol., 62:141-146.

Breves, A.; Miranda, C.; Flores, C.; De Filippis, I. and Clementino, $M$. (2015): Methicillin- and vancomycin-resistant

Staphylococcus aureus in health care workers and medical devices. J. Bras. Patol. Med. Lab., 51(3): 143-152.

BSAC (British Society for Antimicrobial Chemotherapy) (2002): BSAC Standardized Disc Susceptibility Testing Method (version 14) January 2015 available at http:// bsac.org.uk/wp-content/uploads/ 2012/02/BSAC-disc-susceptibilitytesting-method-Jan-2015.pdf

CLSI (Clinical and Laboratory Standards Institute) (2011): Performance standards for antimicrobial susceptibility testing: Twenty First Informational Supplement M100S21.Wayne, PA.

Cremonesi, P.; Luzzana, M.; Brasca, M.; Morandi, S.; Lodi, R.; Vimercati, C.; Agnellini, D.; Caramenti, G.; Moroni, $P$. and Castiglioni, $B$. (2005): Development of a multiplex PCR assay for the identification of Staphylococcus aureus enterotoxigenic strains isolated from milk and dairy products. Mol. Cell Probes, 19: 299-305.

Dinges, M.M.; Orwin, P.M. and Schlievert, P.M. (2000): Enterotoxins of Staphylococcus aureus. Clin. Microbiol. Rev., 13: 16-34.

El-Banna, T.; Sonbol, F.; Abdel-Aziz, A. and El-Ekhnawy, E. (2015): 
Characterization of Vancomycin Resistant Staphylococcus aureus in Tanta University Hospital. Int. J. Curr. Microbiol. App. Sci., 4(10): 1-11.

Elmaghraby, Manal, S.; Abden, Eman, E.; Abou-Elros, Nahla, A. and Elbagory, A. (2018): Molecular identification of virulence genes of Staphylococcus aureus isolated from milk products. Alexandria J. Vet. Sci., 54 (1): 57-64.

FDA (2001): Food and Drug Administration (Bacteriological Analytical Manual). Staphylococcus aureus. Chapter: 12, January 2001.http://www.fda. gov/Food/ScienceResearch/Laborat oryMethods/BacteriologicalAnalyti calManualBAM/UCM071429.htm

Finegold, S.M. and Martin, W.J. (1982): Bailey and Scott Diagnostic Microbiology. $6^{\text {th }}$ Ed., C.V. Mosby Co., St. Louis, Toronto, London.

Hammad, A.M.; Watanabe, W.; Fujii, T. and Shimamoto, T. (2012): Occurrence and characteristics of methicillin-resistant and susceptible Staphylococcus aureus and methicillin-resistant coagulasenegative staphylococci from Japanese retail ready-to-eat raw fish. J. Food Microbiol., 156: 286289.

Hoque, M.N.; Das, Z.C.; Rahman, A.N.; Haider, M.G. and Islam, M.A. (2018): Molecular characterization of Staphylococcus aureus strains in bovine mastitis milk in Bangladesh. Int. J. Vet. Sci. Med., 6:53-60.

Jablonski, L.M. and Bohach, G. (2001): Staphylococcus aureus. In: Doyle M.P.; Beuchat L.R. and Montville T.J. (eds): Food Microbiology: Fundamentals and Frontiers. ASM Press, Washington: p. 411-434.

Janštová, B.; Necidová, L. and Janštová, B. (2012): Comparing the growth of Staphylococcus aureus and production of staphylococcal enterotoxin $\mathrm{c}$ in sheep's and goat's milk. J. Microbiol. Biotechnol. Food Sci., 1: 758-768.

Jay, M.J.; Loessner, J.M. and Golden, A.D. (2005): Staphylococcal gastroenteritis. In: Modern Food Microbiology. $7^{\text {th }}$ ed. Springer Science, New York, pp 545-560.

Johnson, W.M.; Tyler, S.D.; Ewan, E.P.; Ashton, F.E.; Pollard, D.R. and Rozee, K.R. (1991): Detection of genes for enterotoxins, exfoliative toxins, and toxic shock syndrome toxin 1 in Staphylococcus aureus by the polymerase chain reaction. $\mathrm{J}$. Clin. Microbiol., 29: 426-430.

Jung, H.; Cho, J.; Park, S.; Ha, S. (2005): Genotypic and phenotypic characteristics of Staphylococcus aureus isolates from lettuces and raw milk. Korean J. Food. Sci. Technol., 37 (1): 134-141.

Kamal, Rania, M.; Bayomi, M.A.; AbdelAal, S.F. (2013): MRSA detection in raw milk, some dairy products and hands of dairy workers in Egypt, a mini-survey. Food Control, 33: 49-53.

Kluytmans, J.; Van Leeuwen, W.; Goessens, W. (1995): Food-initiated outbreak of methicillin-resistant Staphylocococcus aureus analyzed by pheno and genotyping. J. Clin. Microbiol., 33: 1121-1128.

Krumperman, P.H. (1983): Multiple antibiotic resistance indexing of Escherichia coli to identify highrisk sources of fecal contamination of foods. Appl. Environ. Microbiol., 46: 165-170.

Lampert, L.M. (1975): Modern Dairy Products. $3^{\text {rd }}$ Ed., Chemical Pub. Co., Inc., New York.

Le Loir, Y.; Baron, F. and Gautier, M. (2003): Staphylococcus aureus and food poisoning. Genet. Mol. Res., 2(1): 63-76.

Lee, J. (2003): Methicillin (Oxacillin) resistant Staph. aureus strains isolated from major food animals and their potential transmission to 
humans. App. Environ. Microbiol., 69 (11): 6489-6494.

Mansour, A.S.; Wagih, G.E.; Morgan, S.D.; Elhariri, M.; El-Shabrawy, M.A.; Abuelnaga, A.S.M. and Elgabry, E.A. (2017): Detection of Staphylococcus aureus enterotoxigenic strains in bovine raw milk by reversed passive latex agglutination and multiplex polymerase chain response. Vet. World, 10(8): 843-847.

Meshref, A.; Hassan, G.; Riad, E. and Ashour, W. (2019): Studies on enterotoxigenic Staphylococcus aureus in milk and some dairy products. Assiut Vet. Med. J., 65 (163): 87-97.

Moellering, R.C. (2008): Current treatment options for community-acquired methicillin-resistant

Staphylococcus aureus infection. Clin. Infect. Dis., 46:1032-1037.

Normanno, $\quad G ; \quad L a$ Salandra, G.; Dambrosio, A.; Quaglia, N.C.; Corrente, M.; Parisi, A.; Santagada, G.; Firinu, A.; Crisetti, E. and Celano, G.V. (2007): Occurrence, characterization and antimicrobial resistance of enterotoxigenic Staphylococcus aureus isolated from meat and dairy products. Int. J. Food Microbiol., 115(3):290-296.

Omoshaba, E.O.; Ojo, O.E.; Sofela, O. and Onifade, O.I. (2018): Prevalence and antibiotic resistance patterns of methicillin-resistant

Staphylococcus aureus in raw milk and soft cheese (wara) sold in Abeokuta, Nigeria. Sokoto J. Vet. Sci., 16 (1): 1-8.

Orwin, P.M.; Fitzgerald, J.R.; Leung, D.Y.; Gutierrez, J.A.; Bohach, G.A. and Schlievert, P.M. (2003): Characterization of Staphylococcus aureus enterotoxin L. Inf. Immunit., 71: 2916-2919.

Papadopoulos, P.; Papadopoulos, T.; Angelidis, A.; Boukouvala, E.; Zdragas, A.; Papa, A.;
Hadjichristodoulou, C. and Sergelidis, D. (2018): Prevalence of Staphylococcus aureus and of methicillin-resistant Staph. aureus (MRSA) along the production chain of dairy products in north-western Greece. Food Microbiol., 69: 4350.

Pinchuk, I.V.; Beswick, E.J. and Reyes, V.E. (2010): Staphylococcal enterotoxins. Toxins, 2:2177-2197.

Rall, V.L.M.; Vieira, F.P.; Rall, R.; Vieitis, R.L.; Fernandes, A.Jr.; Candeias, J.M.G.; Cardoso, K.F.G. and Araujo, J.P.Jr. (2008): PCR detection of staphylococcal enterotoxin genes in Staph. aureus strains isolated from raw and pasteurized milk. Vet. Microbiol., 132: 408-413.

Reischl, M.; Ehret, W. and Wolf, H. (1994): PCR-based detection of mycobacteria in sputum samples using a simple and reliable DNA extraction protocol. Bio Techniques, vol. 17 , no. 5 , pp. $844-$ 845.

Sadek, O.A.; Amin, M.M. and Hussein, M.F. (2014a): Comparison between the microbiological status of raw and pasteurized milk yoghurt. Assiut Vet. Med. J., 60 (142): 132138.

Sadek, O.A.; Sayed, S.M.; El Berbawy, S.M.; Mansy, Mariam, F. and Hussien, M.F. (2014b): Some antibiotic resistant bacteria of public health hazard isolated from raw milk sold in some Assiut City markets. Assiut Univ. Bull. Environ. Res., 17(1): 97-107.

Sidhu, M.S.; Oppegaard, H. Devor, T.P. and Sorum, H. (2007): Persistence of multidrug-resistant Staphylococcus haemolyticus in an animal veterinary teaching hospital clinic. Microb. Drug. Resist., 13(4):271-280.

Wang, W.; Baloch, Z.; Jiang, T.; Zhang, C.; Peng, Z.; Li, F.; Fanning, S.; Ma, A. and $X u, \quad J$. (2017): 
Enterotoxigenicity

and

Antimicrobial

Resistance

of

Staphylococcus aureus Isolated from Retail Food in China. Front. Microbiol., 8:2256.doi: 10.3389/ fmicb.2017.02256

Wang, W.; Lin, X.; Jiang, T.; Peng, Z.; Xu, $J . ; Y i, L . ; L i, F . ;$ Fanning, $S$. and Baloch, Z. (2018): Prevalence and characterization of Staphylococcus aureus cultured from raw milk taken from dairy cows with mastitis in Beijing, China. Front. Microbiol., 9:1123. doi: 10.3389/fmicb.2018.01123

Wang, X., Meng, J., Zhang, J., Zhou, T., Zhang, Y., Yang, B. (2012): Characterization of Staphylococcus aureus isolated from powdered infant formula milk and infant rice cereal in China. Int. J. Food Microbiol. 153, 142-147. doi: 10.1016/j.ijfoodmicro.2011.10.030

WHO (2007): The world health report - A safer future: global public health security in the $21^{\text {th }}$ century.

Yildirim, T.; Sadati, F.; Kocaman, B. and Siriken, B. (2019): Staphylococcus aureus and Staphylococcal enterotoxin detection in raw milk and cheese origin coagulase positive isolates. Int. J. Sci. Letters, 1(1): 30-41.

Zakary, E.; Nassif, M. and Mohammed, G. (2011): Detection of Staphylococcus aureus in bovine milk and its product by real time PCR Assay. Global J. Biotechnol. Biochemist., 6 (4): 171-177. 


\section{الكثف الجزيئي لجينات السموم المعوية لميكروب المكور العنقودي الذهبي المعزول من اللبن الخام وبعض منتجات الالبان}

\section{أنسي أديب صادق ، أبين منير إبراهيم كُريّير}

E-mail: onsi_2000@yahoo.com Assiut University web-site: www.aun.edu.eg

تهدف هذه الدراسة إلى تحديد مدى نواجد ميكروب المكور العنقودي الذهبي في اللبن الخام وبعض منتجات الالبان وكذلك

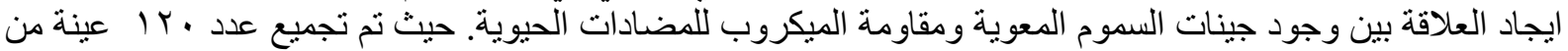

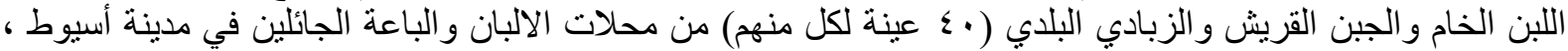

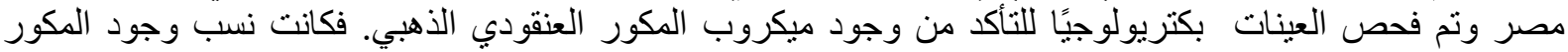

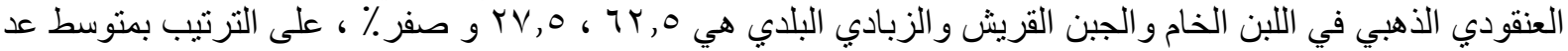

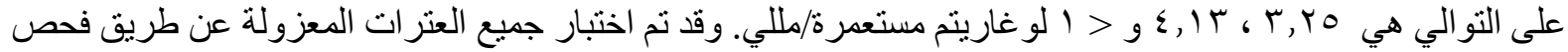
لوجود جينات السموم المعوية PCR

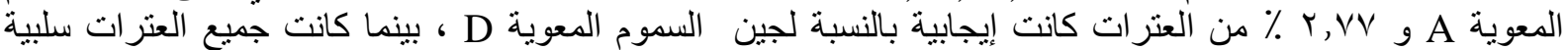

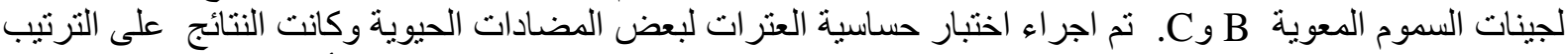

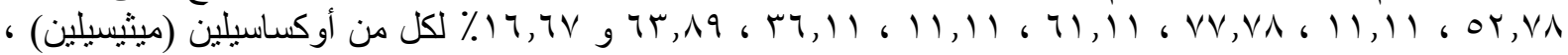

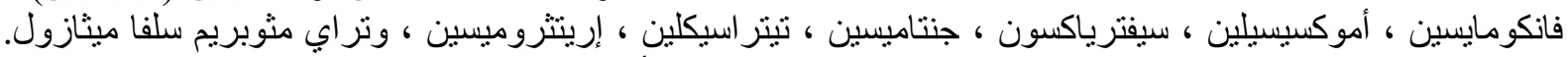

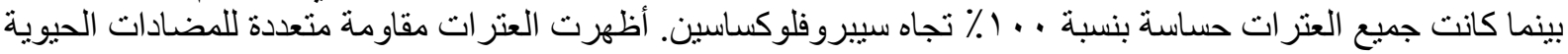

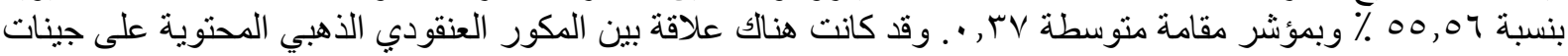

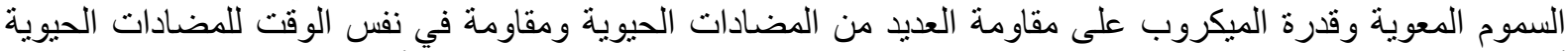

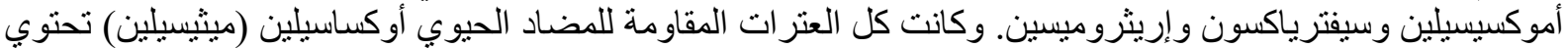

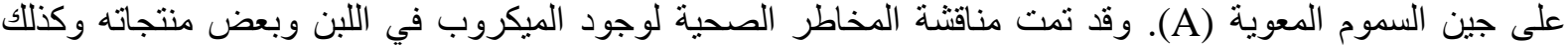
الطرق الصحية الو اجب اتباعها لتقليل خطورة الميكروب محل الدر اسة. 